Bangladesh J. Plant Taxon. 24(2): 219-226, 2017 (December)

(C) 2017 Bangladesh Association of Plant Taxonomists

\title{
POLLEN MORPHOLOGY OF TEUCRIUM L. (LAMIACEAE, AJUGOIDEAE) IN LIBYA
}

\author{
Ream I. Marzouk ${ }^{1}$, Salama M. El-Darier and Abdel Baset M. Askar ${ }^{2}$ \\ University of Alexandria, Faculty of Science, \\ Botany and Microbiology Department, 21511, MoharamBek; Alexandria, Egypt.
}

Keywords: Lamiaceae; Libya; Pollen exine sculpture; SEM; Teucrium.

\begin{abstract}
Pollen grains of 11 taxa of Teucrium from Libya were examined using light microscopy (LM) and scanning electron microscopy (SEM) in order to provide better insight on the evaluation of palynological attributes for species characterization of Teucrium with special emphasis on the five Libyan endemic. Two main pollen shapes were documented; subprolate and prolate or perprolate in $T$. fruticans. The exine sculpture inspected at surface, operculum and pole were mostly verrucate, perforate or scabrate. Teucrium fruticans attained the phenomenon of pollen dimorphism with two distinct shapes and specifics sculpture for each form. The results validated the taxonomic significance of pollen grains for the discrimination among Teucrium species in Libya.
\end{abstract}

\section{Introduction}

Teucrium L. is the second-largest genus of subfamily Ajugoideae with cosmopolitan distribution over represented in the Mediterranean area (Navarro and EL Oualidi, 2000a; Radulović et al., 2012; Yasaman et al., 2016). The Mediterranean region is its main center of diversity, being represented by around $90 \%$ of the total Teucrium species in the world (Blanca et al., 2017).

The pollen attributes were potentially useful for both species identification and phylogenetic implication (Abdel Khalik, 2016). These characters endorsed to be stable and of taxonomic significance for generic and specific delimitation of Teucrium. The size, exine sculpture and density of supratectal elements seemed to be of systematic value (Abu-Assab and Cantino, 1992; Dinç and Ozturk, 2008; Oybak-Dönmez and Inceoğlu, 1988; Oybak-Dönmez et al., 1999; Navarro et al., 2004).

In Libya, Teucrium is represented by eleven taxa of which T. apollinis Maire \& Weiller, $T$. barbeyanum Asch. \& Taub. ex E.A. Durand \& Barratte, T. davaeanum Coss., T. lini-vaccarii Pam. and T. zanonii Pam. are believed to be endemic to Libya (Marzouk et al., 2016).

The present study was performed to assess the taxonomic value of pollen grains for species characterization of Teucrium. It was also achieved to appraise these characters to the Libyan endemic species for the opportunity of their genetic resources conservation.

\section{Material and Methods}

Eleven taxa of Teucrium were collected from eleven locations in Libya, starting from AlGabal Al-Akhdar in the east to Gabal Naffusah (Garian) in the west, along 4500 sq. km. during two flowering seasons: 2009 and 2010. The studied species were sorted under three sections: Chamaedrys, Polium and Teucrium (Table 1). The voucher specimens are kept at the herbaria of Alexandria University (ALEX) and Omar EL-Mukhtar University (Libya).

Corresponding author: Email: reammarzouk@yahoo.com

${ }^{2}$ Omar EL-Mukhtar University; Faculty of Science; El-Beyda; Libya. 
The samples were acetolyzed following Erdtman's technique (Erdtman, 1952). 1-3 specimens for each taxon were subjected in this work; at least 30 pollen grains per taxon were examined by using Zeiss light microscope with a micrometer eye-piece. For SEM, the anthers were transferred directly on a stub with double-sided tape, coated for 5 minutes with gold in a polaron JEC-1100E coating unit, and then photographed with JEOL JSM-5300 SEM (Faculty of Science, Alexandria University). The applied terminology based on Punt et al. (2007).

Table 1. Teucrium specimens used in the present study (sections after Siddiqi, 1985).

\begin{tabular}{|c|c|c|c|}
\hline Section & $\begin{array}{l}\text { Specimen } \\
\text { number }\end{array}$ & Species & Coordinates \\
\hline \multirow[t]{2}{*}{ Chamaedrys } & $1-3$ & *T. barbeyanum Asch. \& & Shahhat Susah \\
\hline & & $\begin{array}{l}\text { Taub. ex E. A. Durand \& } \\
\text { Barratte }\end{array}$ & Coordinate pair: $\mathrm{N} 32^{\circ} 50^{\circ} 30.42 \mathrm{E} 21^{\circ} 51^{\circ} 7.2$ \\
\hline \multirow[t]{13}{*}{ Polium } & $4-6$ & *T. apollinis Maire \& Weiller & \\
\hline & $7-8$ & T. capitatum L. & Tarhonah \\
\hline & & & Coordinate pair: $\mathrm{N} 32^{\circ} 29^{\circ} 48.78 \mathrm{E} 13^{\circ} 37^{\circ} 37.08$ \\
\hline & $9-11$ & *T. davaeanum Coss. & Wadi El Quttarh \\
\hline & & & Coordinate pair: $\mathrm{N} 32^{\circ} 01^{\circ} 35.82 \mathrm{E} 20^{\circ} 24^{\circ} 45.48$ \\
\hline & $12-14$ & *T. lini-vaccarii Pamp. & Quasser-El Quaar \\
\hline & & & Coordinate pair: $\mathrm{N} 32^{\circ} 35^{\circ} 20.28 \mathrm{E} 13^{\circ} 50^{\circ} 18.18$ \\
\hline & $15-17$ & T. polium L. & Sirut \\
\hline & & & Coordinate pair: $\mathrm{N} 31^{\circ} 08^{\circ} 56.1 \mathrm{E} 16^{\circ} 34^{\circ} 35.16$ \\
\hline & $18-19$ & T. polium subsp. flavovirens & Al Hameida escarpment \\
\hline & & Batt. & Coordinate pair: $\mathrm{N} 32^{\circ} 24^{\circ} 52.98$ E $20^{\circ} 32^{\circ} 17.88$ \\
\hline & $20-22$ & *T. zanonii Pamp. & Dryannah \\
\hline & & & Coordinate pair: $\mathrm{N} 32^{\circ} 19^{\circ} 42.12 \mathrm{E} 20^{\circ} 16^{\circ} 34.86$ \\
\hline \multirow[t]{6}{*}{ Teucrium } & $23-25$ & T. brevifolium Schreb. & Lathroun-Ras El Hellal \\
\hline & & & Coordinate pair: $\mathrm{N} 32^{\circ} 52305^{\circ} 0 \mathrm{E} 22^{\circ} 15^{\circ} 6.12$ \\
\hline & $26-28$ & T. campanulatum L. & Wadi Errieg \\
\hline & & & Coordinate pair: $\mathrm{N} 32^{\circ} 32230^{\circ} 0 \mathrm{E} 20^{\circ} 42^{\circ} 56.82$ \\
\hline & $29-30$ & T. fruticans L. & El Rabtta-El Assbeh \\
\hline & & & Coordinate pair: $\mathrm{N} 32^{\circ} 07^{\circ} 12.6 \mathrm{E} 21^{\circ} 52^{\circ} 16.14$ \\
\hline
\end{tabular}

*Endemic species.

\section{Results and Discussion}

The taxonomic complexity of Teucrium is reflected in the changes in its classification using different characteristics as pollen morphology (Díez et al., 1993), karyology (Valdés-Bermejo and Sánchez-Crespo, 1978), indumentum characteristics (Manzanares et al., 1983; El Oualidi and Puech, 1993; Navarro and EL Oualidi, 2000b), phytochemistry (Harborne et al., 1986; VelascoNegueruela and Pérez-Alonso, 1990; Bukhari et al., 2014) and amino acid composition (Juani et al., 2004). Meanwhile, there is an imminent danger for genetic erosion of Libyan wild species due to the increment in drought and anthropogenic activities, that has resulted in habitat loss and fragmentation leading to the diminishing of the germplasm reservoir (Al-Idrissi et al., 1996). The 

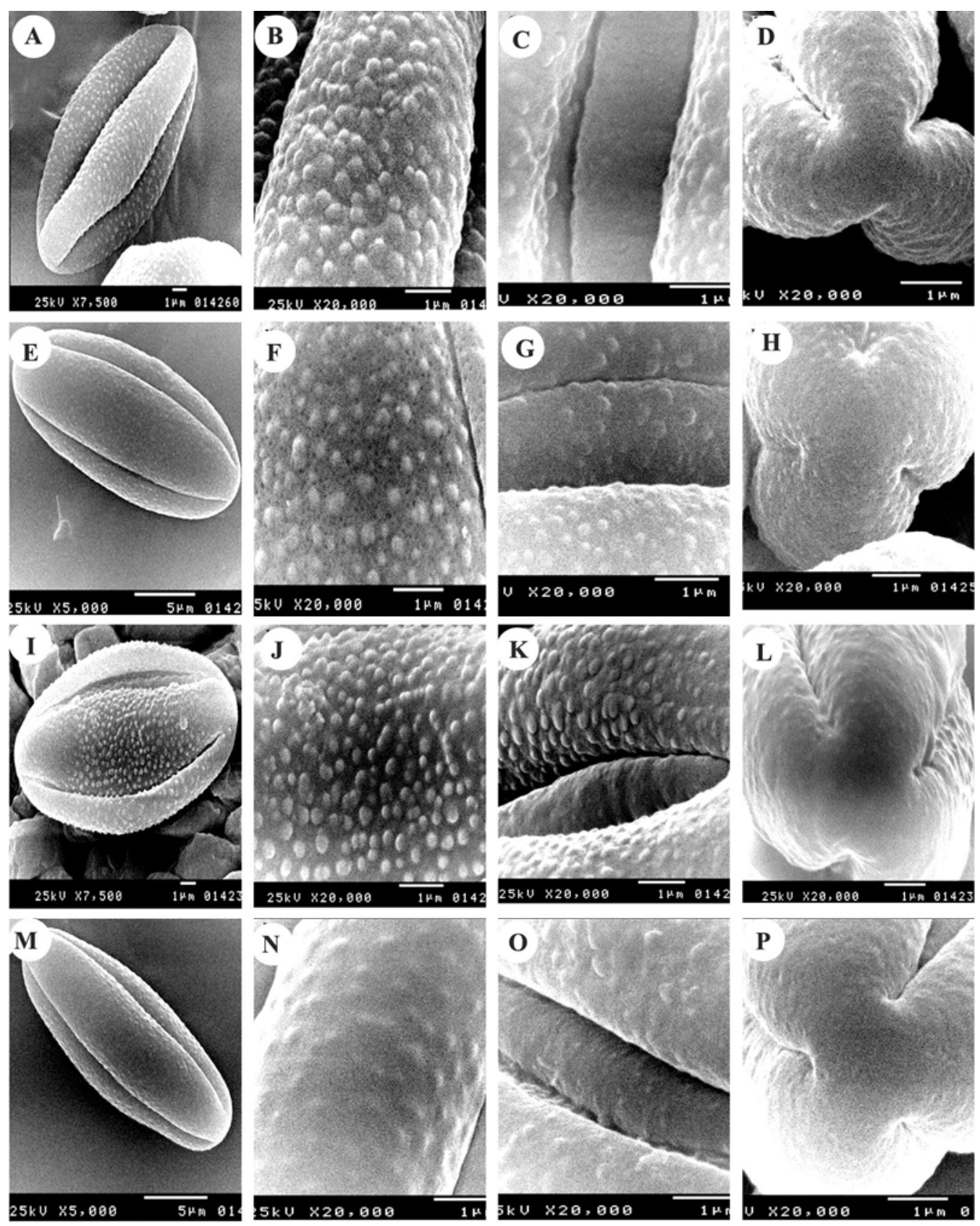

Fig. 1. Pollen grains of Teucrium: A-D, T. barbeyanum; E-H, T. apollinis; I-L, T. capitatum; M-P, T. davaeanum.

IUCN Red List of Threatened Plants (1998) recorded three endemic species; T. apollinis, $T$. barbeyanum and $T$. zanonii in addition $T$. davaeanum and T. lini-vaccari recorded by Marzouk et al. (2016). Consequently, the efforts must be intensified giving priority to study both endangered and endemic species through various characters. 
In the present study, Teucrium pollen grains are monads, isopolar, radio symmetric, and tricolpate with opercula. The pollen shape is subprolate in T. barbeyanum (Fig. 1A), T. campanulatum (Fig. 3A) and T. polium subsp. flavovirens (Fig. 2L) and prolate in the rest of species. However, two shapes were recorded in T. fruticans; perprolate (form a) and prolate (form b) (Fig. 3I, O). That is in congruent with Ojeda and Díez (1992) for the recognition of the dimorphism phenomenon in this species. The polar axis length ranges from 30.02-31.2 $\mu \mathrm{m}$ in section Chamaedrys, from 30.41-37.01 $\mu \mathrm{m}$ in section Polium, and from 38.74-60.96 $\mu \mathrm{m}$ in section
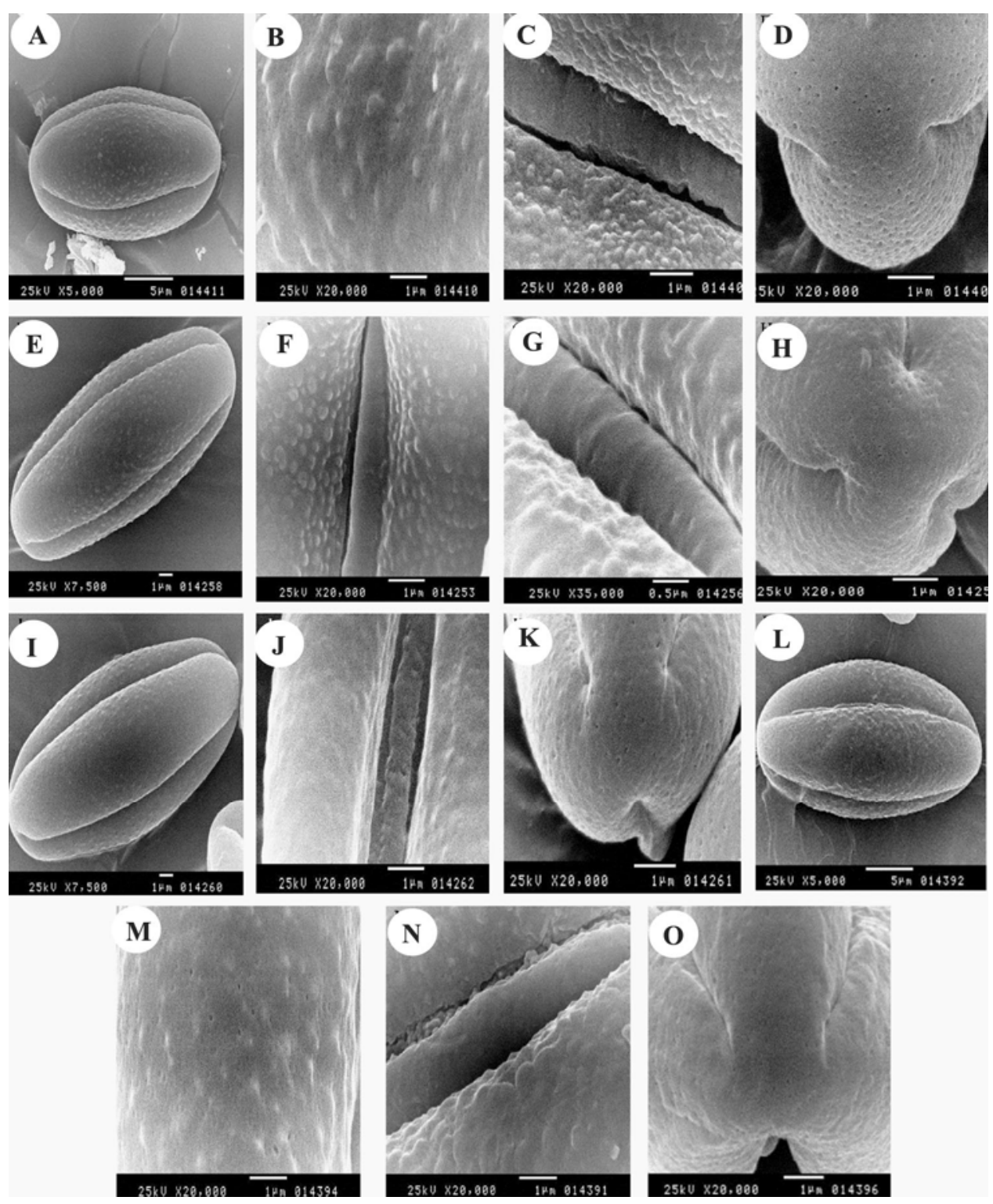

Fig. 2. Pollen grains of Teucrium: A-D, T. lini-vaccarii; E-H, T. polium; I-K, T. polium subsp. flavovirens; $\mathrm{L}-\mathrm{O}, \mathrm{T}$. zanonii. 
Teucrium (Table 2). The equatorial diameter varies from $23.47-28.28 \mu \mathrm{m}$ in both sections Chamaedrys and Polium, and 19.63-39.23 $\mu \mathrm{m}$ in section Teucrium. Polar axis and equatorial diameter were found useful in separating two closely related taxa where it is large in T. polium than T. polium subsp. flavovirens. The largest colpus dimensions and mesocolpium diameter attain in section Teucrium while the smallest in section Polium (Table 2). The exine thickness assorts from 1.5-1.65 $\mu \mathrm{m}$ in T. campanulatum and the taxa of both sections Chamaedrys and Polium, while from 2.33-3.19 $\mu \mathrm{m}$ in the rest of section Teucrium (Table 2). Oybak-Dönmez and Inceoğlu (1988) and Dinç et al. (2008) specified Teucrium with either verrucate or verrucate-granulate exine sculpture, meanwhile Navarro et al. (2004) declared that the basal groups of Teucrium with verrucate sculpturing. The current study discriminates among the exine sculpture at the surface,
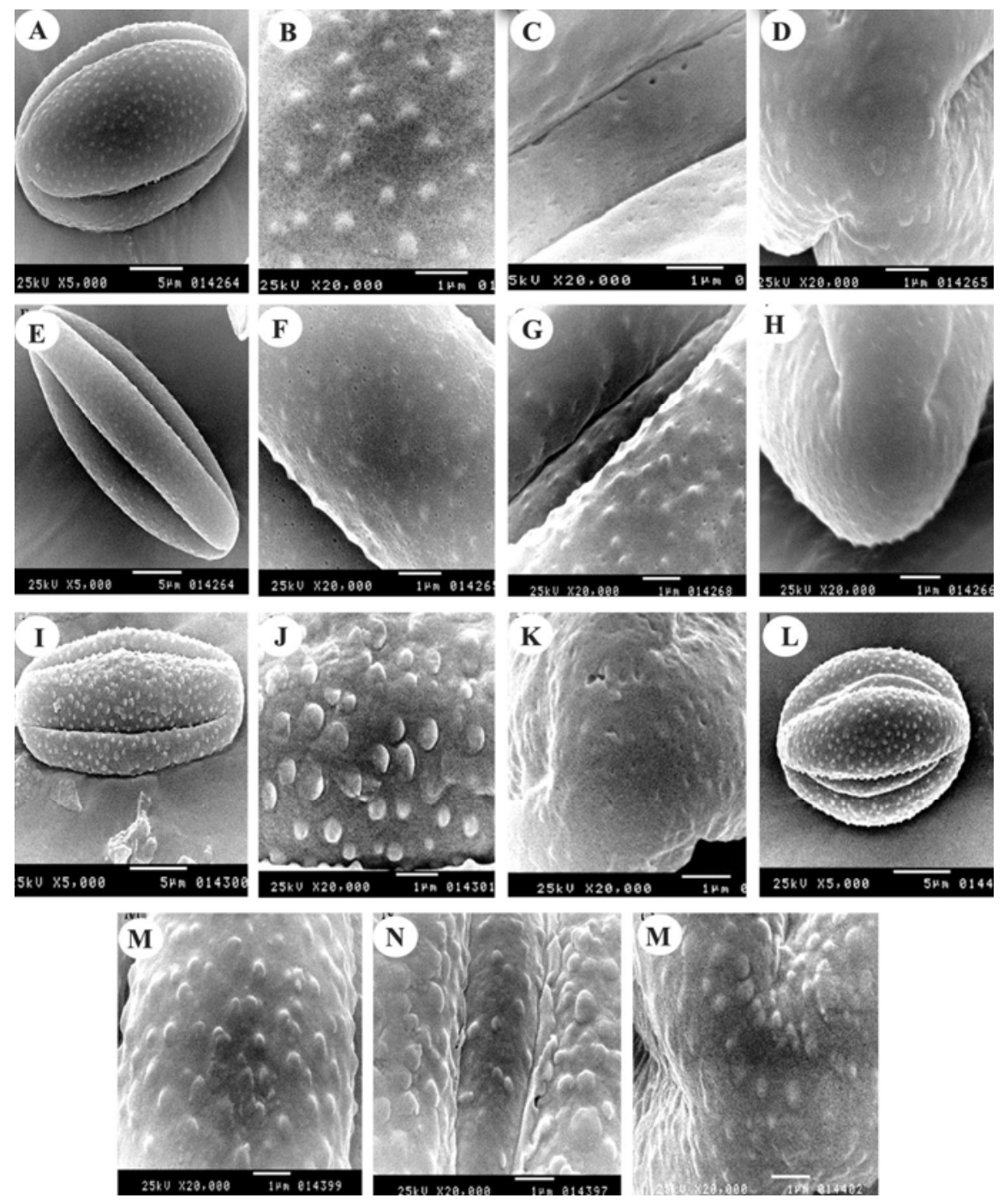

Fig. 3. Pollen grains of Teucrium: A-D, T. brevifolium; E-H, T. campanulatum; I-K, T. fruticans form a; $\mathrm{L}-\mathrm{O}, \mathrm{T}$. fruticans form $\mathrm{b}$. 


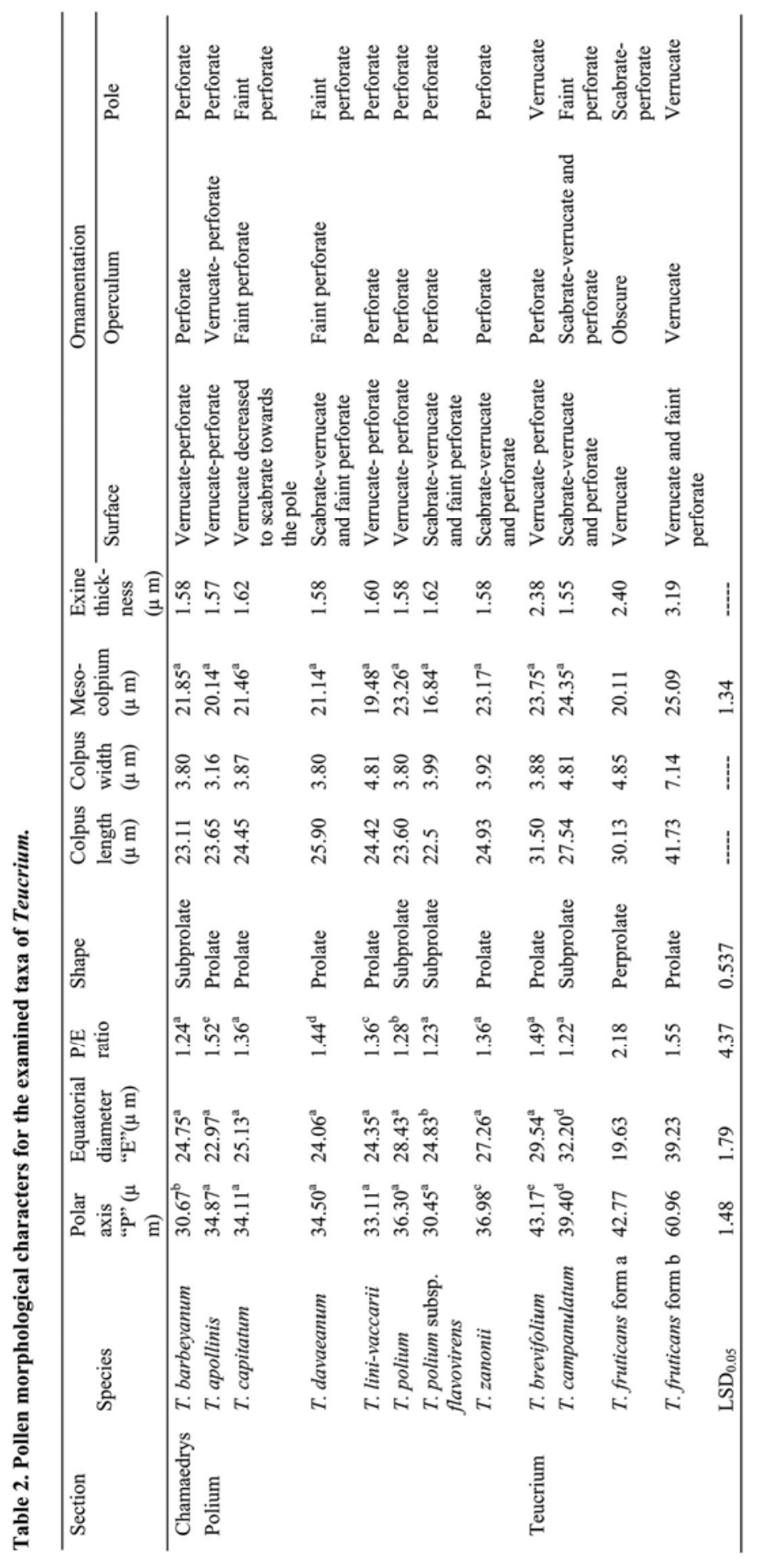


operculum and pole. In section Chamaedrys, the exine sculpture is verrucate-perforate at the surface and perforate at both operculum and pole (Fig. 1B, D). In section Polium, the verrucateperforate surface sculpture accomplishes with T. apollinis (Fig. 1F), T. lini-vaccarii (Fig. 2B) and T. polium (Fig. 2F). While in T. capitatum (Fig. 1J, K) and T. polium subsp. flavovirens (Fig. 2J), the sculpture is verrucae to scabrate. Both $T$. davaeanum and $T$. zanonii specify with sculpture of scabrate-verrucate and faint perforate (Fig. 1N) and scabrate-verrucate and perforate (Fig. 2M), respectively. The faint perforate sculpture at both operculum and pole realizes in both $T$. capitatum (Fig. 1K, L) and T. davaeanum (Fig. 1O, P), while T. apollinis with verrucate-perforate at the operculum (Fig. 1K) and perforate in the rest of species. In section Teucrium, each species attains certain sculpturing, T. brevifolium reveals verrucate-perforate, perforate, and verrucate at the surface, operculum and pole, respectively (Fig. 3B, D). In T. campanulatum, the sculpture is scabrate-verrucate and perforate at both surfaces and operculum and faint perforate at the pole (Fig. 3F, H). Teucrium fruticans accomplishes sculpture dimorphism, the verrucate or verrucate and faint perforate at the surface (Fig. 3J, M), obscure or verrucate at the operculum (Fig. 3I, N), and scabrate-perforate or verrucate at the pole (Fig. $3 \mathrm{~K}, \mathrm{O}$ ). The results indicated the validity of pollen characters for taxonomic implications and in the discrimination among Teucrium at both section and species levels.

\section{References}

Abdel Khalik, K. 2016. A systematic revision of the genus Plectranthus L. (Lamiaceae) in Saudi Arabia based on morphological, palynological, and micromorphological characters of trichomes. American Journal of Plant Sciences 7: 1429-1444.

Abu-Assab, M.S. and Cantino, P.D. 1992. Pollen morphology in subfamily Lamioideae (Lamiaceae) and its phylogenetic implications. In: Harley, R.M. and Reynolds, T.(Eds), Advances in Lamiaceae Science. Royal Botanic Gardens, Kew, pp. 97-122.

Al-Idrissi, M., Sbeita, A., Jebriel, A., Zintani, A., Shreidi, A., Ghawawi, H. and Tazi, M. 1996. Libya: Country report to the FAO international technical conference on plant genetic resources. Leipzig, Germany.

Blanca, G., Cueto, M. and Fuentes, J. 2017. Teucrium teresianum sp. nov. (Lamiaceae) from southern Spain. Nordic J. Bot. 35(1): 14-19.

Bukhari, N.A., Al-Otaibi, R.A. and Ibrahim, M.M. 2014. Biodiversity characteristics of Teucrium polium species in Saudi Arabia. Saudia J. Biol. Sci. 22(2): 181-185.

Díez, M.J., Ojeda, F. and Colomer, M. 1993. Contribución a la palinolog1 a del genero Teucrium L. en la Penınsula Iberica e Islas Baleares y suinteretaxonmico. Lagascalia 17: 119-134.

Dinç, M. and Ozturk, M. 2008. Comparative morphological, anatomical, and palynological studies on the genus Stachys L. sect. Ambleia Bentham (Lamiaceae) species in Turkey. Turkish J. Bot. 32:113-121.

Dinç, M., Duran, A., Pinar, M. and Ozturk, M.2008. Anatomy, palynology and nutlet micromorphology of Turkish endemic Teucrium sandrasicum (Lamiaceae). Biologia 63: 637-641.

El Oualidi, J. and Puech, S. 1993. Quelques marqueurs morphologiques des Teucrium section Polium (Lamiaceae) du Maroc: valeurs diagnostiques à différents niveaux d'integration. Acta Botanica Malacitana 18:163-171.

Erdtman, G. 1952. Pollen Morphology and Plant Taxonomy. Angiosperms. Almqvist and Wiksell, Stockholm, pp. 539.

Harborne, J.B., Tomas-Barberan, F.A., Williams, C.A. and Gil, M.I. 1986. A chemotaxonomic study of flavonoids from European Teucrium species. Phytochemistry 25: 2811-2816.

IUCN Red List of Threatened Plants. 1998. Walter, K.S. and Gillett, H.J. (Eds),1997. IUCN Compiled by the World Conservation Monitoring Centre. IUCN-The World Conservation Union, Gland, Switzerland and Cambridge, UK, pp. 862. 
Juani, R., Pastor, J., Milla, F., Alaiz, M. and Vioque, J. 2004. Amino acids composition of Teucrium nutlet proteins and their systematic significance. Ann. Bot. 94: 615-621.

Manzanares, P., Gómez-Campo, G. and Tortosa, M.E. 1983. Estudiossobre el indumento de las especiesibéricasy baleáricas del género Teucrium L. (Lamiaceae). Anales del Jardín Botánico de Madrid 40: 94-106.

Marzouk, R.I., El-Darier, S.M. and Askar A.M. 2016. Nutlet micromorphological characters of Teucrium taxa (Lamiaceae) in Libya. Phytotaxa 263(3): 245-254.

Navarro, T. and El Oualidi, J. 2000a. Sinopsis of Teucrium L. (Labiatae) in the Mediterranean region and surrounding areas. Flora Mediterranea 10: 349-363.

Navarro, T. and El Oualidi, J. 2000b. Trichome morphology in Teucrium L. (Labiatae), a taxonomic review. Anales del Jardín Botánico de Madrid 57: 277-297.

Navarro, T., El Oualidi, J. and Trigo D.M. 2004. Pollen morphology of Teucrium (Labiatae) and its taxonomic value. Belgian J. Bot. 137(1): 70-84.

Ojeda, F. and Díez, M.J. 1992. Pollen dimorphism in three Teucrium species (Lamiaceae). Plant Syst. Evol. 183: 43-49.

Oybak-Dönmez, E. and Inceoğlu, Ö. 1988. Pollen morphology of some Teucrium L. (Labiatae) species. Communications Faculty of Sciences University of Ankara Series C: Biology 6: 133-146.

Oybak-Dönmez, E., Inceoğlu, Ö. and Pinar, N.M. 1999. Scanning electron microscopy study of pollen in some Turkish Teucrium L. (Labiatae). Turkish J. Bot. 23: 379-382.

Punt, W., Hoen, P.P., Blackmore, S., Nilsson, S. and Le Thomas, A. 2007. Glossary of pollen and spore terminology. Review of Palaeobotany \& Palynology 143: 1-81.

Radulović, N., Dekić, M., Joksović, M. and Vukićević, R. 2012. Chemotaxonomy of Serbian Teucrium species inferred from essential oil chemical composition: the case of Teucrium scordium L. ssp. scordioides. Chemistry and Biodiversity 9:106-122.

Siddiqi, M.A. 1985. 3: Teucrium. In: Jafri, S.M.H. and El-Gadi, A. (Eds), Flora of Libya. Al Faateh University, Faculty of Science, Department of Botany, Tripoli, pp. 13-30.

Valdés-Bermejo, E. and Sánchez-Crespo, A. 1978. Datos cariologicos sobre el genero Teucrium L. (Labiatae) en la Peninsula Ibérica. Acta Botánica Malacitana 4: 27-54.

Velasco-Negueruela, A. and Pérez-Alonso, M.J. 1990. The volatiles of six Teucrium species from the Iberian Peninsula and the Balearic Islands. Phytochemistry 29: 1165-1169.

Yasaman, S., Stefan, K., Günther, H. and Christian, B. 2016. Phylogeny of non-monophyletic Teucrium (Lamiaceae: Ajugoideae): implications for character evolution and taxonomy. Taxon. 65(4): 805-822. 